\title{
FRUIT YIELD OF EUROPEAN CRANBERRY (Oxycoccus palustris Pers.) IN DIFFERENT PLANT COMMUNITIES OF PEATLANDS (NORTHERN WIELKOPOLSKA, POLAND)
}

\author{
Artur Adamczak ${ }^{1 *}$, Maciej Gąbka², Waldemar Buchwald ${ }^{1}$ \\ ${ }^{1}$ Department of Botany, Breeding and Agronomy, Institute of Natural Fibres and Medicinal Plants \\ Kolejowa 2, 62-064 Plewiska, Poland, e-mail: wbuchwald@iripz.pl \\ ${ }^{2}$ Department of Hydrobiology, Institute of Environmental Biology, Faculty of Biology, Adam Mickiewicz University \\ Umultowska 89, 61-614 Poznań, Poland, e-mail: gmaciej@amu.edu.pl \\ * corresponding author: \\ e-mail: artur.adamczak@interia.pl
}

Received: 20.02 .2009

\section{Abstract}

The aim of this study was to determine fruit yield of Oxycoccus palustris under the climatic and habitat conditions of northern Wielkopolska (the Greater Poland region), depending on the type of occupied plant community. Total fruit number and fruit weight as well as average cranberry leaf size were determined on 33 plots with an area of $1 \mathrm{~m}^{2}$, located on 7 peatlands. On the study areas, European cranberry produced crops from 9.2 up to $242.0 \mathrm{~g} \times \mathrm{m}^{-2}$, which gives $92-2420 \mathrm{~kg}$ $\times$ ha $^{-1}$. It has been demonstrated that on the peatlands of northern Wielkopolska $O$. palustris reaches its generative and vegetative optimum in the communities of the class Scheuchzerio-Caricetea fuscae, in particular in the community Sphagno recurvi-Eriophoretum angustifolii.

Key words: Oxycoccus palustris, Ericaceae, growth, crop, peatlands, medicinal plants, plant communities, vegetation

\section{INTRODUCTION}

Oxycoccus palustris Pers. is an evergreen shrublet of the family Ericaceae with a wide range of occurrence. It occupies Sphagnum bogs of the Northern Hemisphere. As a commercial plant, it plays a special role in the Northern and Eastern Europe area as well as in Siberia. In Russia it is the most important species among all wild growing berry plants (G ro c how s k i, 1976; B oč and M a z in g, 1988; P l o t $\mathrm{nik} \mathrm{o} \mathrm{v}$ and $\breve{\mathrm{S}} \mathrm{mid} \mathrm{t,} \mathrm{1988).} \mathrm{It} \mathrm{is} \mathrm{estimated} \mathrm{Finland's}$ average annual cranberry crops can be more than 20 million $\mathrm{kg}$ ( $\mathrm{R}$ a a t i k a i n e $\mathrm{n}, 1988)$.

European cranberry fruit is used in the food and pharmaceutical industries. It is an excellent addi- tive to meat as well as juice drinks, jams, jellies, etc., are produced from it. Similarly to American cranberry - Oxycoccus macrocarpos (Aiton) Pursh, it contains large amounts of organic acids (including vitamin C) as well as pectins, flavonoids, anthocyanins and other active compounds ( M u r a v' e v and Š a ti l o, 1973; Jensen et al. 2002; Ehala et al. 2005; Kozłowski et al. 2006). Research on American cranberry shows that species of the genus Oxycoccus can be used in the treatment of urinary tract infections as well as in the prevention of heart diseases and ulcer diseases of the digestive system. Cranberry fruit extracts show antibacterial and antifungal activity (e.g. Lai et al. 2000; Rodow ski, 2001; S tothers, 2002).

In Poland cranberry resources are limited, though this plant occurs across our whole country. Its stands are concentrated in the northern, southern and eastern parts of Poland: in Pomorze (Pomerania), Warmia and Mazury (Masuria), Górny Śląsk (Upper Silesia), the western Kielce region and the southern part of the Łódź region as well as in Polesie and the Lublin region ( $\mathrm{Zaj}$ ą $\mathrm{c}$ and $\mathrm{Z}$ aj ą c eds. 2001). This species also belongs to shrublets frequently encountered on peat and transitional bogs of Wielkopolska (e.g. G ą b k a et al. 2007).

Research on cranberry fruit yield has not been conducted in Poland so far. Information on Oxycoccus palustris resources and its fruit yield, as well as on habitat conditions which determine them, come primarily from Russian peatlands (e.g. Š u t o v, 1985; Ne kr a t o va et al. 1986; Č e rk a s o v, 1988; P l o tn i k o v and Š midt, 1988; Ûd in a, 1997; K u r lo - 
vi č and K o s i c yn, 2000). Many authors (e.g. R a j ko and S a u tin, 1973; S n i gire v and Hve s' ko, 1978; A l e k s e e va, 1986; N e k rat o v a et al. 1986; Kopoteva and Kupcova, 1997) point out that the productivity of this species is related to the peatland type and vegetation differentiation, as described according to the approach of the Russian school.

This paper attempts to determine fruit yield of European cranberry under the climatic and habitat conditions of northern Wielkopolska, depending on the type of occupied plant community (according to the Braun-Blanquet approach).

\section{MATERIALS AND METHODS}

The field study was carried out in September 2008 on 7 Sphagnum bogs located within the area of the city of Piła in northern Wielkopolska (Tab. 1). These were oligotrophic peat bogs (Tab. 1, sites 1-4) or medium fertile transitional bogs developing near hu- mic lakes, advanced in the process of disappearance (sites 5-7). In accordance with the physico-geographical division of Kondracki (2002), these sites are situated in the macroregion of the Southern Pomerania Lakelands and they cover the southern part of the Gwda River valley.

33 study areas of $1 \mathrm{~m}^{2}$ were established on the investigated peatlands. Plots of this size are commonly used to determine cranberry fruit yield (e.g. Š u t o v , 1985; Čerkas ov, 1988; Kurlovi č and Kosic y $n, 2000)$. On each plot, all cranberry fruits were collected and 9 shoots of this species were sampled in a systematic way. The fruits were weighed and counted, and from the shoots one leaf was sampled for the measurement of leaf blade length and width. Additionally, 30 randomly selected fruits from each plot were weighed. A smaller amount of fruits (respectively, 18 and 21) was collected from two plots. In total, 969 fruits were weighed and the length and width of 297 cranberry leaves were measured.

Table 1

The location of peatlands and number of vegetation plots.

\begin{tabular}{|c|c|c|c|c|}
\hline No. & Peatlands & Administrative unit & Geographical coordinates & $\begin{array}{c}\text { No. of vegetation } \\
\text { plots }\end{array}$ \\
\hline 1 & $\begin{array}{l}\text { Nameless peatland near } \\
\text { Zelgniewo }\end{array}$ & Kaczory & $\mathrm{N} 53^{\circ} 10^{\prime} 09^{\prime \prime}$ E $16^{\circ} 52^{\prime} 14^{\prime \prime}$ & 5 \\
\hline 2 & $\begin{array}{l}\text { Nameless peatland between } \\
\text { Skórka and Jeziorki }\end{array}$ & Piła & N 53 $10^{\prime} 19^{\prime \prime}$ E $16^{\circ} 52^{\prime} 12^{\prime \prime}$ & 7 \\
\hline 3 & $\begin{array}{l}\text { Peatland by W part of lake } \\
\text { Czarne near Kaczory }\end{array}$ & Kaczory & N $53^{\circ} 07^{\prime} 23^{\prime \prime}$ E $16^{\circ} 54^{\prime} 56^{\prime \prime}$ & 5 \\
\hline 4 & Peatland near lake Okoniowe & Piła & $\mathrm{N} 53^{\circ} 11^{\prime} 18^{\prime \prime} \mathrm{E} 16^{\circ} 47^{\prime} 56^{\prime \prime}$ & 5 \\
\hline 5 & $\begin{array}{l}\text { Peatland by lake Czarne near } \\
\text { Jeziorki }\end{array}$ & Kaczory & N $53^{\circ} 08^{\prime} 45^{\prime \prime}$ E $16^{\circ} 51^{\prime} 34^{\prime \prime}$ & 3 \\
\hline 6 & Peatland Kuźnik Olszowy & Szydłowo & $\mathrm{N} 53^{\circ} 12^{\prime} 46^{\prime \prime} \mathrm{E} 16^{\circ} 43^{\prime} 38^{\prime \prime}$ & 4 \\
\hline \multirow[t]{2}{*}{7} & Peatland Kuźnik Bagienny & Szydłowo & N 53 12' 53" E $16^{\circ} 43^{\prime} 53^{\prime \prime}$ & 4 \\
\hline & Summary & & & 33 \\
\hline
\end{tabular}

Table 2

Variability of Oxycoccus palustris in the investigated peatlands. Median, minimal, maximal value and quartile variability coefficient of cranberry crop and some biometric properties.

\begin{tabular}{lcccc}
\hline \multicolumn{1}{c}{ Variables } & Median & Min. & Max. & V [\%] \\
\hline Total no. of fruits & 174 & 18 & 829 & 98.85 \\
Total weight of fruits [g] & 47.1 & 9.2 & 242.0 & 152.02 \\
Weight of fruit [g] & 0.31 & 0.01 & 1.09 & 67.74 \\
Length of leaf [mm] & 9.43 & 5.63 & 13.95 & 27.04 \\
Width of leaf [mm] & 4.57 & 2.59 & 6.94 & 22.98 \\
\hline
\end{tabular}


The study areas were set up in separate vegetation patches, at sites of the abundant occurrence of European cranberry as well as in different types of bog phytocoenoses. The designated plots were located at a distance of at least $10 \mathrm{~m}$ from each other (usually 20-40 m). A floristic inventory was conducted in each square, determining percentage species cover as well as the cover of the moss layer and total cover of all vascular plants, excluding Oxycoccus palustris.

The syntaxonomic classification of cranberry patches within the plots was made based on phytosociological relevés of the phytocoenoses on which the study areas were located. The nomenclature of phytosociological units followed a list of plant communities of Wielkopolska made by B r ze g and W o j ter s k a (2001).

Statistica 7.1 software (StatSoft, 2005) was used for calculations. In statistical analysis, standard parametric tests were used: Student's test, Cochran-Cox test, Pearson coefficient of correlation, as well as nonparametric tests: gamma test, Mann-Whitney test and Kruskal-Wallis test. The Shapiro-Wilk test was used to assess the normality of variable distribution, whereas the F-test, Lévene's test and Brown-Forsyth test were used to assess the equality of variance in comparable groups. In order to normalise the distribution of the analysed variables, outliers were removed in justified cases (not more than one in a particular group).

\section{RESULTS}

Fruiting European cranberry was documented in 6 communities of the transitional and peat bogs. These were phytocoenoses representing the following associations: Sphagno tenelli-Rhynchosporetum albae Osvald 1923 nom. invers., Sphagno recurvi-Eriophoretum angustifolii Hueck 1925 nom. invers. et nom. mut., Sphagno apiculati-Caricetum rostratae Osvald 1923 em. Steffen 1931 (class Scheuchzerio-Caricetea fuscae) as well as Sphagnetum magellanici (Malcuit 1929) Kästner et Floßner 1933, Sphagno recurvi-Eriophoretum vaginati Hueck 1925 nom. invers. and LedoSphagnetum magellanici Sukopp 1959 ex Neuhäusl 1969 (class Oxycocco-Sphagnetea). On the study areas, the cranberry cover ranged between $10 \%$ and $90 \%$ (on the average 50\%). The cover of other vascular plant species was from $5 \%$ up to $80 \%$ (on the average $40 \%$ ). The moss layer was very well-developed, usually with the cover of $80-100 \%$ (Fig. 1).

European cranberry showed large variations in fruit weight and leaf size (length and width). A large variability was also observed in fruit yield of this species: total fruit number and weight of fruits collected from the designated areas (Tab. 2). The variability in question was associated with phytosociological differentiation of the communities. In the transitional bog phytocoenoses of the class

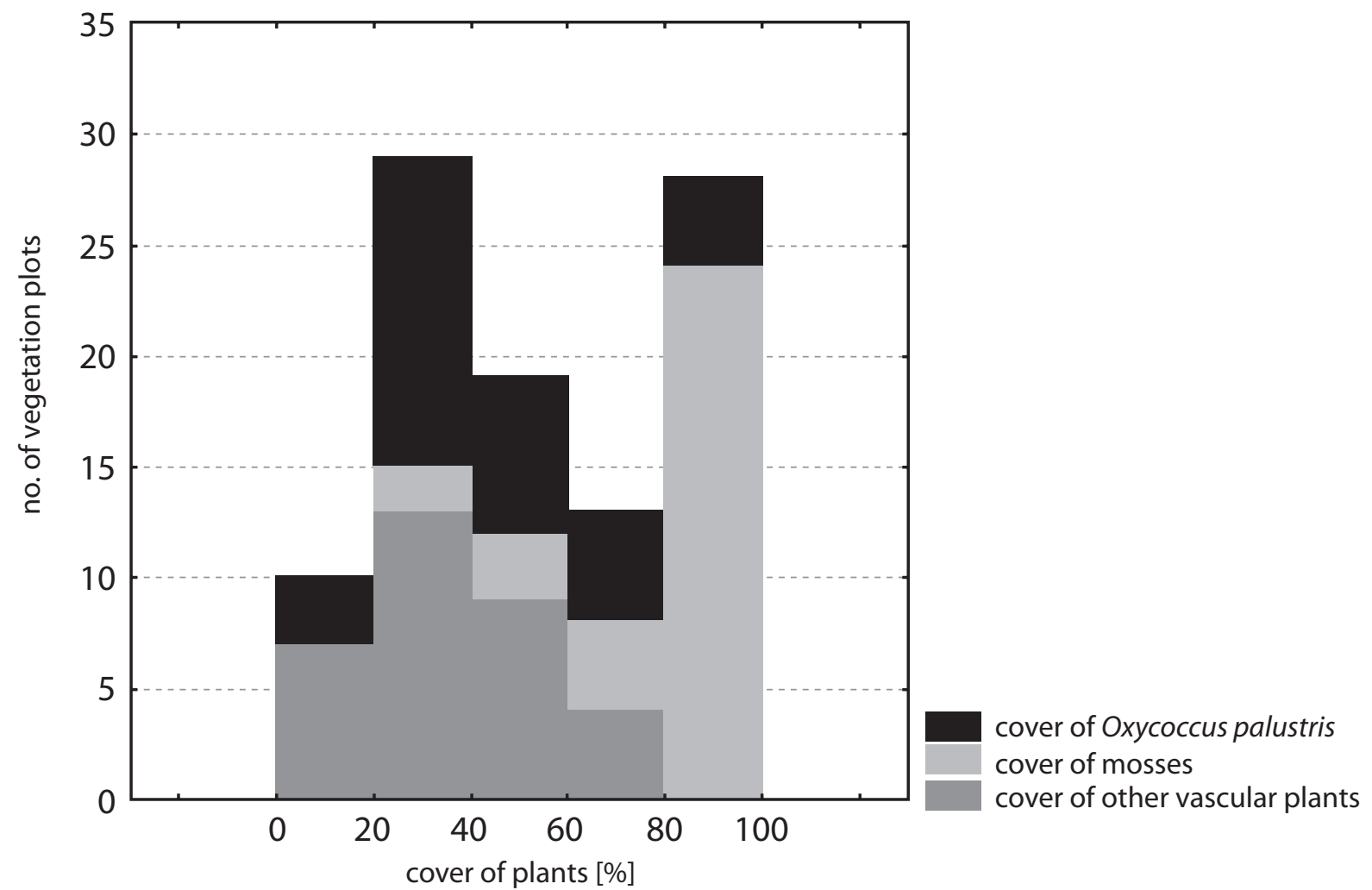

Fig. 1. Differentiation of the cover of Oxycoccus palustris, other vascular plants and mosses [\%] in vegetation plots of peatlands. 
A

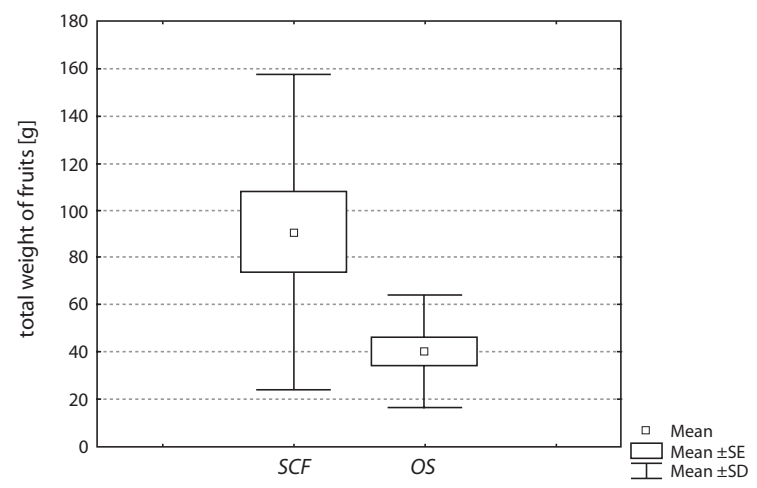

C

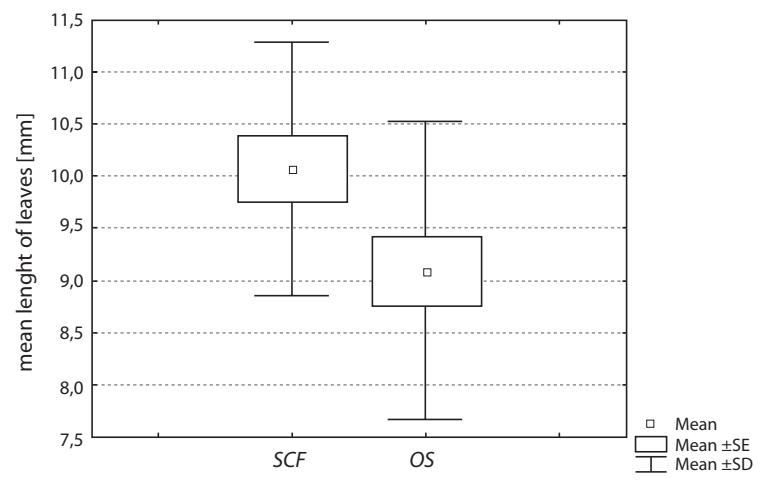

$\mathbf{E}$

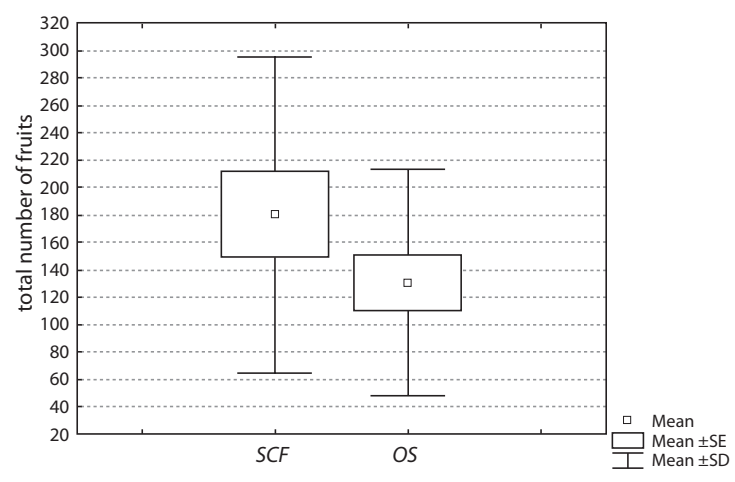

B

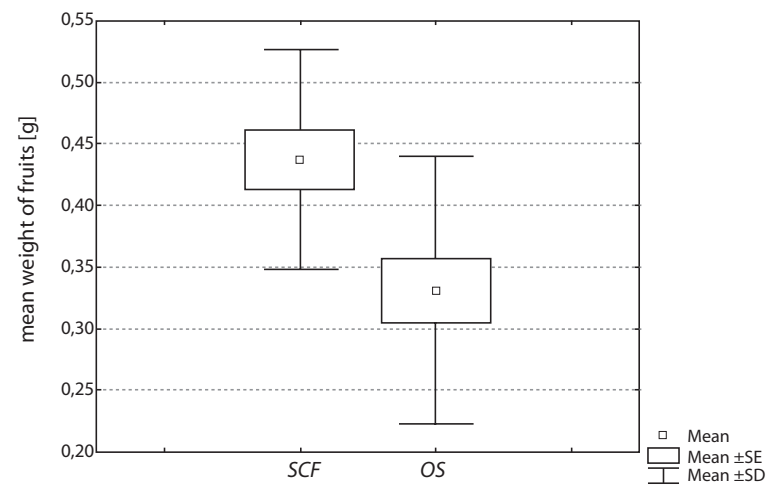

D

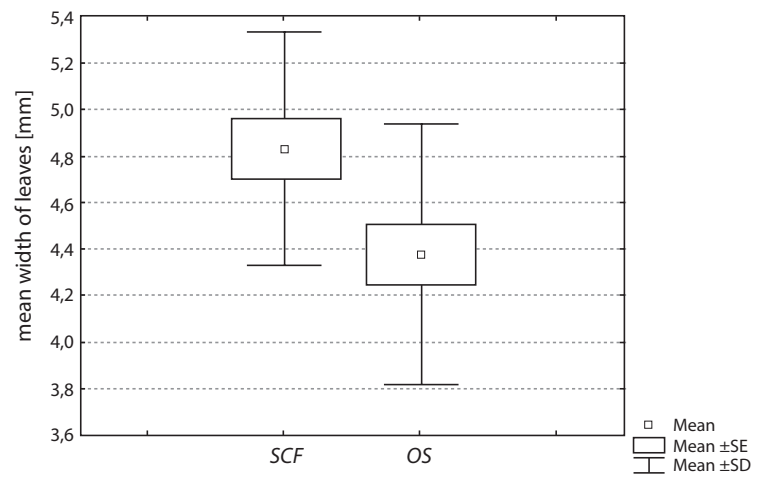

$\mathbf{F}$

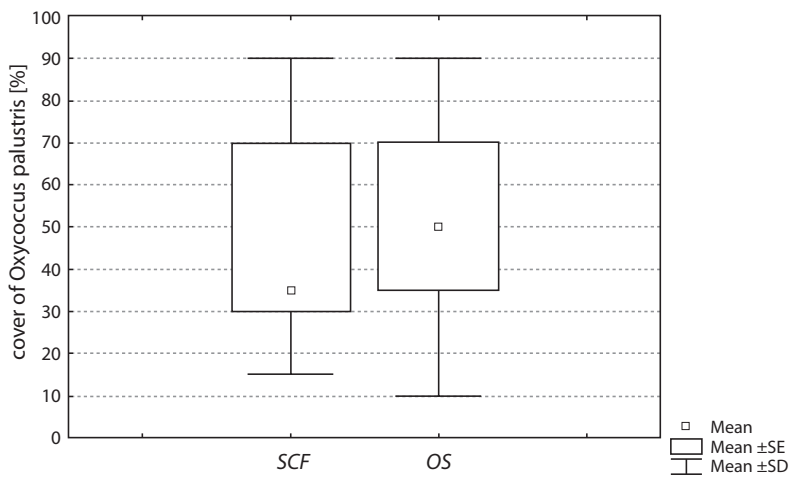

Fig. 2. Differentiation of cranberry crop and some biometric properties in vegetation plots of the phytocoenoses from ScheuchzerioCaricetea fuscae (SCF) and Oxycocco-Sphagnetea (OS) classes.

A) Cochran-Cox test: 2.7739; $<<0.05 ; \mathrm{n}=32$; B) Student's test: 3.0250; $\mathrm{p}<0.01 ; \mathrm{n}=33$;

C) Student's test: $2.0936 ; \mathrm{p}<0.05 ; \mathrm{n}=33$; D) Student's test: $2.4366 ; \mathrm{p}<0.05 ; \mathrm{n}=33$;

E) Student's test: 1.3964; N.S.; $n=31$; F) Mann-Whitney test: 103.5000; N.S.; $n=33$. 

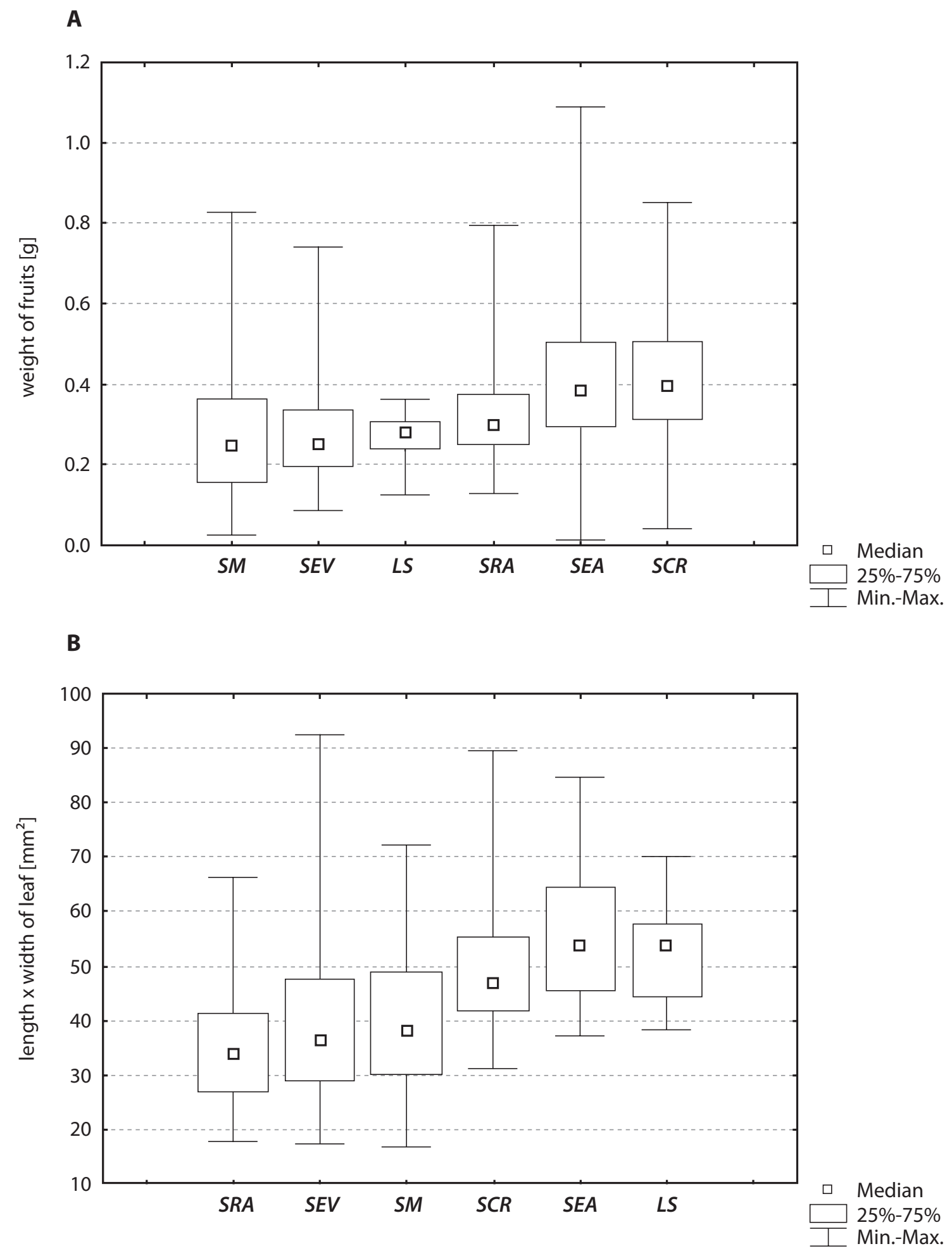

Fig. 3. Differentiation of the weight of fruits (A) and the size of leaves (B) of Oxycoccus palustris in phytocoenoses of the Scheuchzerio-Caricetea fuscae and Oxycocco-Sphagnetea classes.

A) Kruskal-Wallis test: 147.91; $\mathrm{p}<0.001 ; \mathrm{n}=969$; B) Kruskal-Wallis test: 82.73; $\mathrm{p}<0.001 ; \mathrm{n}=297$.

Oxycocco-Sphagnetea class: SM Sphagnetum magellanici, SEV - Sphagno recurvi-Eriophoretum vaginati LS - LedoSphagnetum magellanici; Scheuchzerio-Caricetea fuscae class: SRA - Sphagno tenelli-Rhynchosporetum albae, SEA - Sphagno recurvi-Eriophoretum angustifolii, SCR - Sphagno-Caricetum rostratae. 


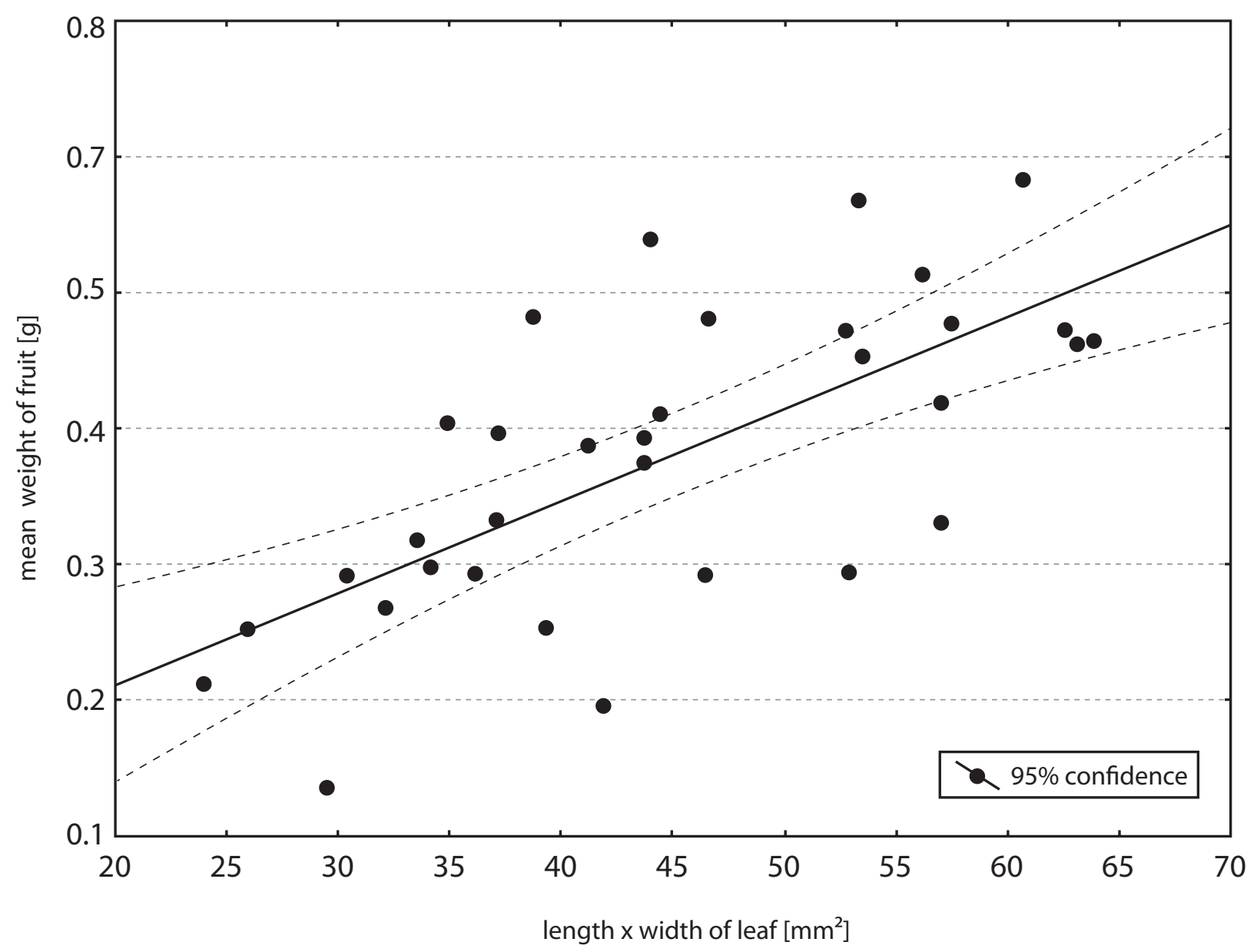

Fig. 4. Correlation between the size of leaves and mean weight of fruits of Oxycoccus palustris in vegetation plots. Pearson coefficient of correlation: $0.69 ; \mathrm{p}<0.001 ; \mathrm{n}=33$.

Scheuchzerio-Caricetea fuscae, total and average fruit weight, as well as average length and width of cranberry leaf blade, were statistically significantly higher than in the peat bog patches of the class $O x y$ cocco-Sphagnetea (Fig. 2). However, in the abovementioned groups of communities, no significant differences were found as regards total fruit number on the designated areas and the cover of Oxycoccus palustris on the patches (Fig. 2). At the plant association level, statistically significant differences were found for such cranberry traits as fruit weight and leaf size (Fig. 3). It should be stressed that the percentage cover of cranberry, as well as of other vascular plants and the moss layer, had no impact on fruit yield of the species concerned (total fruit number and fruit weight as well as average fruit weight). But a clear correlation was found between the average weight of cranberry fruit on the study areas and the average size of its leaves (Fig. 4).

\section{DISCUSSION AND CONCLUSIONS}

On the study plots, European cranberry produced crops from 9.2 up to $242.0 \mathrm{~g} \times \mathrm{m}^{-2}$, which gives $92-2420 \mathrm{~kg} \times \mathrm{ha}^{-1}$. These are values comparable to the data obtained from Russian, Lithuanian, Belarusian and Ukrainian peatlands (e.g. R a jko and S a u t in, 1973; S n igire v and Hve s' k o, 1978; B očar ov and Kurlovič, 1988; B oč and Mazing, 1988; Čerkas ov, 1988; Ripa, 1988; Krasnov and Orlov, 1996). Fruit yield of cranberry growing in these areas ranges between 3 and $2622 \mathrm{~kg} \times \mathrm{ha}^{-1}$. Due to changing weather conditions, it is subject to large variations depending on the study year ( $\breve{S}$ uto v, 1985; A lek seeva, 1986; B očar ov and Ku rlovič, 1988; Ûdina, 1988; Krasnov and Orlov, 1996).

According to some authors (e.g. Š u to v, 1985; A l e k s e e v a, 1986), cranberry fruit yield in the mid- 
dle and southern zones of the Russian taiga is more affected by weather conditions than ecophytocenotic factors. However, the water table level (e.g. B o č a r o v and K u rlovič, 1988; K u r lovi č and K o s i c y n, 2000) and habitat richness (Ûd i n a 1988) also perform an important role. The study presented in this article shows that European cranberry produces better yields (higher total and average fruit weight) in the communities of the transitional bogs than in those of the peat bogs (Fig. 2). Oxycoccus palustris fruit reaches the highest weight in the phytocoenoses of the types Sphagno-Caricetum rostratae and Sphagno-Eriophoretum angustifolii of the order Scheuchzerietalia palustris (Fig. 3). R a j k o and S a ti n (1973) as well as Alekseeva (1986) also indicate higher fruit yields of cranberry occupying mesooligotrophic habitats (transitional bogs) compared to oligotrophic peat bogs.

Oxycoccus palustris is characterised by a wide ecological scale. It is found both on poor oligotrophic peat bogs as well as on medium fertile and fertile types of Sphagnum bogs (e.g. A s a d a , 2000; B r a g a z z a et al. 2005; N a vrátilová and N a vrátil, 2005; $\mathrm{G}$ ą b k a and L a me n t o w i c z, 2008). It is considered to be a species characteristic for the class OxycoccoSphagnetea (B r z e g and W o j te r s k a, 2001) or the order Sphagnetalia magellanici (M atus z ki ew i c z, 2005); thus, from the phytosociological point of view, it has its occurrence optimum in peat bog phytocoenoses. However, our study shows that European cranberry not only produces better yields, but also develops larger leaves in the transitional-bog, not peatbog, communities (Figs 2, 3). Among the investigated communities of the class Scheuchzerio-Caricetea fuscae, cranberry had the lowest fruit yield and luxuriance in the patches with a predominance of Rhynchospora alba. These phytocoenoses developed in the complex of peat bogs which had an influence on the poor (oligotrophic) nature of the communities with White Beak-sedge. The luxuriant growth of vegetative and generative organs in Oxycoccus palustris growing on the transitional bogs most probably resulted from the greater richness of these habitats compared to the poor and strongly acid peat bogs ( $\mathrm{H}$ á j e $\mathrm{k}$ et al. 2002). Additionally, nutrient availability for plants increases in the habitats with the groundwater $\mathrm{pH}$ of 6-7 ( $\mathrm{R} \mathrm{y} \mathrm{d} \mathrm{in}$ and $\mathrm{J}$ e $\mathrm{g} 1 \mathrm{u} \mathrm{m}, 2006$ ).

European cranberry is characterised by large variations in the morphological features of its vegetative and generative organs (G u g n a c k a - F i e d or, 1986; U din a, 1988; Gronsk is and Sniskovs k i s , 1989). Tetra-, penta- and hexaploid forms of this species are known (Gugnacka-Fiedor, 1983; R a vanko, 1990; A hokas, 1996; Suda and L y s á k, 2001), and they may sometimes occur together even on a very small area of a bog ( $\mathrm{S} \mathrm{u} \mathrm{d} \mathrm{a} \mathrm{,} \mathrm{2002).}$
Nevertheless, the presence of different cytotypes in Oxycoccus palustris does not explain the morphological variability of this species. In the opinion of $\mathrm{S} \mathrm{u} \mathrm{d} \mathrm{a}$ and L y s á k (2001), tetra-, penta- and hexaploid forms of European cranberry are very difficult to distinguish based both on their morphological features and data on their ecology, phenology and distribution. That is why they relinquished from delineating intraspecific units in Oxycoccus palustris. Gug nacka-Fied or (1986) included plants with fine leaves and fruit in the subspecies $O$. palustris Pers. subsp. microphyllus (Lange) Löve et Löve, whereas she distinguished large-leaved and large-fruited forms as a new variety O. palustris Pers. subsp. palustris var. macrophyllus Gug. The positive correlation, found during the study presented in this paper, between average leaf size and average fruit weight on the study areas is interesting in this context (Fig. 4).

It seems that European cranberry forms differing in their leaf and fruit size are habitat-conditioned ecotypes; hence larger fruit and leaves in $O x y$ coccus palustris on the transitional bogs (Figs 2, 3). It should be emphasised that Hagerup (1940) described specimens with shoots which had both fine and large leaves. In turn, G u g n a c k a - F i e d or (1986) showed that in changed habitat conditions (after the transfer of portions of the population from 4 sites to another bog), the shape and size of cranberry leaves also undergo great changes. B o č a r o v and K u r lovi č (1988) observed on drained peatlands cranberry with smaller, reddish-coloured leaves. An increase in cranberry leaf size was noted by $\hat{U} \mathrm{~d}$ in a (1988) after the application of mineral fertilisation on the bog.

In Central and Eastern Europe a standard research method for studying the vegetation of bog ecosystems is the synecological approach ( $\mathrm{M}$ a t u s Z ki e w i c z, 2005). Analysis based on the typological classification of vegetation has enabled us in this study to determine fruit yield of European cranberry depending on the community type in phytosociological terms. It has been demonstrated that on the peatlands of northern Wielkopolska Oxycoccus palustris reaches its generative and vegetative optimum in some communities of the class Scheuchzerio-Caricetea fuscae.

The relationship between the species composition of bog vegetation and habitat parameters (in particular, groundwater chemistry) and the determination of their effect on the biometric features of cranberry require further detailed research. The results of this type of analysis are being currently processed by the authors. The abovementioned research will allow abiotic requirements of Oxycoccus palustris to be identified more precisely and the optimum of this species in phytosociological terms to be determined more accurately. 


\section{Acknowledgments}

The authors would like to thank Prof. dr habil. Jan Kozłowski of the Institute of Natural Fibres and Medicinal Plants for his critical comments on this article. This study was financed by the Ministry of Science and Higher Education under a research project no. N40502231/1319.

\section{REFERENCES}

A h ok a s H., 1996. Is the polyploid cranberry (Vaccinium sp.) in Finland tetraploid or hexaploid? Nord. J. Bot. 16 (2): 185-189.

Alekseeva R. N., 1986. Dinamika urožajnosti âgod Oxycoccus palustris Pers. na bolotah $\mathrm{v}$ bassejne srednej Vyčegdy (Komi ASSR). / Dynamics of berry yield of Oxycoccus palustris Pers. on swamps of the middle Vychegda River (Komi ASSR) Rast. Resursy, 22 (2): 172-178.

A s a d a T., 2000. Distribution of two taxa in Vaccinium oxycoccus sensu lato (Ericaceae) along micro-scale environmental gradients in Bekanbeushi peatland, northern Japan. Acta Phytotax. Geobot. 51: 169-176.

B oč M. S., Mazing V. V., 1988. Resursy bolot SSSR: ih ocenka i ispol'zovanie. / Resources of peatlands in SSSR: evaluation and use their. Rast. Resursy, 24 (1): $3-12$.

B o č a r o v I. V., K u rl o v i č L.E., 1988. Sostoânie i urožajnost' Oxycoccus palustris L. na intensivno osušennyh pušicevo-sfagnovyh verhovyh bolotah (Kalininskaâ oblast'). / State and productivity of Oxycoccus palustris L. on intensively drained cotton grass-sphagnum high bogs in Kalinin Oblast. Rast. Resursy, 24 (4): 498-502.

Bragazza L., Rydin H., Gerdol R., 2005. Multiple gradients in mire vegetation: a comparison of Swedish and an Italian bog. Plant Ecology, 177: 223-236.

Brzeg A., Wojterska M., 2001. Zespoły roślinne Wielkopolski, ich stan poznania i zagrożenie. / Plant communities of Wielkopolska region, recognition and their vulnerability. [In:] Szata roślinna Wielkopolski i Pojezierza Południowopomorskiego. M. Wojterska (ed.), Przewodnik sesji terenowych 52. Zjazdu PTB, Bogucki Wyd. Nauk., Poznań: 39-110.

Črkas ov A. Ph., 1988. The cranberry yield in the USSR. Acta Bot. Fennica, 136: 65-68.

Ehala S., Vaher M., Kaljur and M., 2005. Characterization of phenolic profiles of Northern European berries by capillary electrophoresis and determination of their antioxidant activity. J. Agric. Food Chem. 53: 64846490.

Gąbka M., La mentowicz M., 2008. Vegetation-environment relationship in peatlands dominated by Sphagnum fallax in western Poland. Folia Geobot. 43: 413-429.

Gąbka M., Owsianny P. M., Sobczyński T., 2007. Comparison of the habitat conditions of peat-moss phytocoenoses dominated by Eriophorum angustifolium
Honck. or Carex rostrata Stokes from mires in Western Poland. Biodiv. Res. Conserv. 5-8: 61-69.

Grochowski W., 1976. Uboczna produkcja leśna. PWN, Warszawa, 571.

Gronsk is I., Sn ickovsk is A., 1989. Organization of cranberry growing in Latvia. Acta Horticult., 241: 77-80.

Gugnacka-Fiedor W., 1983. The variability of phenol compounds based on karyological studies of taxa of the genus Vaccinium L., subgenus Oxycoccus (Hill) A. Gray. Acta Soc. Bot. Pol. 52 (1): 87-99.

Gugnacka-Fied or W., 1986. Zmienność morfologiczna taksonów rodzaju Oxycoccus Hill. / Morphological variability of taxa of the genus Oxycoccus Hill. St. Soc. Scient. Tor. Sect. D 11 (4): 1-56.

Ha g e r u p O., 1940. Studies on the significance of polyploidy. IV. Oxycoccus. Hereditas, 26: 399-410.

Hájek M., Hekera P., Hájková P., 2002. Spring fen vegetation and water chemistry in the Western Carpathian flysch zone. Folia Geobot. 37: 205-224.

Jensen H. D., Krogfelt K. A., Cornet t C., Hansen S. H., Christensen S. B., 2002. Hydrophilic carboxylic acids and iridoid glycosides in the juice of American and European cranberries (Vaccinium macrocarpon and $V$. oxycoccos), lingonberries (V. vitis-idaea), and blueberries (V. myrtillus). J. Agric. Food Chem. 50: 6871-6874.

K o n d r a ck i J., 2002. Geografiaregionalna Polski. Państwowe Wydawnictwo Naukowe, Warszawa, 450.

Kopoteva T. A., Kupcova V. A., 1997. Fitocenotičeskie osobennosti i urožajnost' âgod Oxycoccus palustris Pers. v Priamur'e. / Phytocenological peculiarity and crop of Oxycoccus palustris Pers. growth in Pryamurie. Rast. Resursy, 33 (4): 75-80.

Kozłowski J., Buchwald W., Mścisz A., Mielcarek S., Forycka A., Szczyglewska D., Przybylak J., Mroziki ew icz P. M., 2006. Celowość badań fitochemicznych nad żurawiną błotną i możliwość jej zastosowania w fitoterapii. / Usefulness of phytochemical research on Oxycoccus palustris Pers. and possibility of its use in phytotherapy. [In:] Blueberry and cranberry growing (with ecological aspects). Book of Abstracts. Instytut Sadownictwa i Kwiaciarstwa, Skierniewice: 229-235.

Krasnov V. P., Orlov A. A., 1996. Urožajnost' osnovnyh âgodnyh rastenij iz sem. Ericaceae na Ukrainskom Polec'e i vozmožnost' èkspluatacii ih resursov posle černobyl'skoj katastrofy. / Productivity of main berrybearing plants from the family Ericaceae in Ukrainian Polessie and possibility of exploitation of their resources after Chernobyl nuclear accident. Rast. Resursy, 32 (1-2): 41-48.

Kurlovič L. E., Kosicyn V. N., 2000. Vliânie gidrolesomeliorativnyh rabot različnoj intensivnosti na proektivnoe pokrytie i urožajnost' Oxycoccus palustris Pers. $\mathrm{v}$ treh oblastâh evropejskoj časti Rossii. / Influence of hydroforestmelioration works of different intensity on the projective cover and productivity of Oxycoccus 
palustris Pers. in three regions of European part of Russia. Rast. Resursy, 36 (4): 17-23.

Lai Y. F., Yinrong L., Howell A. B., Vorsa N., 2000. The structure of cranberry proanthocyanidins which inhibit adherence of uropathogenic pfimbriated Escherichia coli in vitro. Phytochemistry, 54: 173-181.

Matuszkiewicz W., 2005. Przewodnik do oznaczania zbiorowisk roślinnych Polski. PWN, Warszawa, 540.

Mu rav'e v I. A., Š a tilo V. V., 1973. Himičeskij sostav âgod Oxycoccus quadripetalus Gilib. / Chemical composition of berry of Oxycoccus quadripetalus Gilib. Rast. Resursy, 9 (3): 379-383.

Navrátilová J., Navrátil J., 2005. Vegetation gradients in fishpond mires in relation to seasonal fluctuations in environmental factors. Preslia, 77: 405-418.

Nekratova N. A., Nekratov N. F., Mihajlova S. I., 1986. Resursy lekarstvennyh i âgodnyh rastenij v severnyh rajonah Tomskoj oblasti. / Resources of medicinal and berry plants in the northern areas of Tomsk Oblast. Rast. Resursy, 22 (3): 297-310.

Plotnikov D. A., Šmidt A. S., 1988. Zapasy dikorastuših lekarstvennyh, âgodnyh i plodovyh rastenij v Parabel'skom rajone Tomskoj oblasti. / Resources of wild medicinal, berry and fruit plants in Parabel' Raion of the Tomsk Oblast. Rast. Resursy, 24 (2): 177-182.

Raatikainen M., 1988. Estimates of wild berry yields in Finland. Acta Bot. Fennica, 136: 9-10.

R aj k o P. N., S a u t i n V. I., 1973. Rasprostranenie i urožajnost' klûkvy v lesah Belorussii. / Distribution and yield of cranberry in forest of Belarus. Rast. Resursy, 9 (1): 3-10.

Ravanko O., 1990. The taxonomic value of morphological and cytological characteristics in Oxycoccus (subgenus of Vaccinium, Ericaceae) species in Finland. Ann. Bot. Fennici, 27: 235-239.

R ip a A., 1988. Rational use, reproduction and protection of cranberries in the Latvian SSR. Acta Bot. Fennica, 136: 69-72.

Rodowski D., 2001. Żurawina - nowe spojrzenie na właściwości lecznicze. / Cranberry - new look at medicinal properties. Postępy Fitoterapii, 6: 28-31.

Rydin H., Jeglu m J., 2006. The biology of peatlands. Oxford University Press, 343.

S n i g i r e v G. S., H ve s' k o O. I., 1978. Intensivnost' cveteniâ i plodonošeniâ nekotoryh âgodnyh rastenij v BSSR. / Intensity of flowering and fruiting some berry plants in BSSR. Rast. Resursy, 14 (1): 113-117.

StatSoft, Inc. 2005. STATISTICA (data analysis software system), version 7.1. www.statsoft.com

S tothers L., 2002. A randomized trial to evaluate effectiveness and cost effectiveness of naturopathic cranberry products as prophylaxis against urinary tract infection in woman. Can. J. Urol. 9: 1558-1562.

$\mathrm{S}$ u d a J., 2002. Sympatric occurrences of various cytotypes of Vaccinium sect. Oxycoccus (Ericaceae). Nord. J. Bot. 22 (5): 593-601.
Suda J., Lysák M. A., 2001. A taxonomic study of the Vaccinium sect. Oxycoccus (Hill) W.D.J. Koch (Ericaceae) in the Czech Republic and adjacent territories. Folia Geobot. 36 (3): 303-320.

Šutov V. V., 1985. Vliânie èkologičeskih faktorov na urožajnost' Vaccinium myrtillus i Oxycoccus palustris (Ericaceae). / The effect of ecological factors upon the productivity of Vaccinium myrtillus and Oxycoccus palustris (Ericaceae). Bot. Žurn. 70 (12): 1647-1653.

$\hat{U}$ d in a V. F., 1988. On the European cranberry in Soviet Karelia. Acta Bot. Fennica, 136: 73-76.

Ûdina V. F., 1997. Sostoânie izučennosti lekarstvennyh i âgodnyh rastenij bolot Karelii. / The state of investigations of medicinal and berry plants of mires of Karelia. Rast. Resursy, 33 (4): 109-116.

Z aj ą c A., Z a ją c M. (eds.), 2001. Atlas rozmieszczenia roślin naczyniowych w Polsce. UJ, Kraków: 392.

\section{Plonowanie żurawiny błotnej (Oxycoccus palustris Pers.)}

\section{w różnych zbiorowiskach roślinnych torfowisk (północna Wielkopolska, Polska)}

\section{Streszczenie}

Oxycoccus palustris jest jedną z najważniejszych roślin użytkowych rosnących na torfowiskach północnej półkuli. Celem niniejszych badań było określenie plonowania żurawiny błotnej w warunkach klimatyczno-siedliskowych północnej Wielkopolski, w zależności od typu zajmowanego zbiorowiska roślinnego. Określono całkowitą liczbę i masę owoców oraz średnią wielkość liści żurawiny błotnej na 33 poletkach o powierzchni $1 \mathrm{~m}^{2}$, położonych na 7 torfowiskach. Analizowano występowanie Oxycoccus palustris w trzech zbiorowiskach z klasy Scheuchzerio-Caricetea fuscae oraz trzech z klasy OxycoccoSphagnetea. Na wytyczonych powierzchniach żurawi-

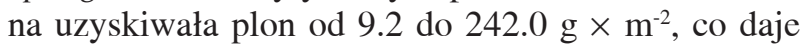
92-2420 kg $\times$ ha $^{-1}$. Wykazano znaczną zmienność badanych cech omawianego gatunku. Stwierdzono dodatnią korelację między średnią wielkością liści a średnią masą owoców na poletkach. Można sądzić, że opisywane przez innych autorów taksony: $O$. palustris Pers. subsp. microphyllus (Lange) Löve et Löve i O. palustris Pers. subsp. palustris var. macrophyllus Gug., to dwa warunkowane siedliskowo ekotypy żurawiny błotnej.Wykazano, że na torfowiskach północnej Wielkopolski $O$. palustris osiąga optimum generatywne i wegetatywne w zbiorowiskach z klasy Scheuchzerio-Caricetea fuscae, szczególnie w zbiorowisku Sphagno recurvi-Eriophoretum angustifolii. 